\title{
Developing and validating the Arabic version of the Diabetes Quality of Life questionnaire
}

Walid Al-Qerem, ${ }^{1}$ Buthaina Al-Maayah ${ }^{1}$ and Jonathan Ling ${ }^{2}$

${ }^{1}$ Al-Zaytoonah University of Jordan, Faculty of Pharmacy, Amman, Jordan (Correspondence to: W. Al-Qerem: waleed.qirim@zuj.edu.jo). ${ }^{2}$ University of Sunderland, Faculty of Health Sciences and Wellbeing, Sunderland, United Kingdom.

\begin{abstract}
Background: The Diabetes Quality of Life (DQoL) questionnaire has been used frequently among people with diabetes. Aims: To develop and validate a revised Arabic version of the DQoL questionnaire for patients in Jordan with type 2 diabetes.

Methods: We recruited patients with type 2 diabetes from 3 public health clinics in Jordan. The original DQoL questionnaire was translated to Arabic and then back-translated by a different translator, and the 2 versions were compared. Prior to circulating the final version of the questionnaire, a cognitive validity test was applied to ensure that all the questions were clear. The final Arabic version of the DQoL questionnaire, along with a questionnaire that included demographic and other health-related questions, were circulated to the participants. The questionnaire data were analysed using exploratory factor analysis and confirmatory factor analysis after excluding duplicated questions and questions that included $>10 \%$ missing data. Cronbach's $\alpha$ was also conducted to confirm internal consistency.
\end{abstract}

Results: Analysis validated an Arabic version of DQoL questionnaire that included 29 items divided into 3 factors: worries, impact and satisfaction. Different variables were associated with DQoL scores including insulin administration, low income status, marital status, and presence of diabetic complications.

Conclusions: We validated an Arabic tool that can be used to evaluate QoL among Arabic-speaking patients with type 2 diabetes.

Keywords: Arabic, Diabetes Quality of Life Instrument, Jordan, type 2 diabetes

Citation: Al-Qerem W; Al-Maayah B; Ling J. Developing and validating the Arabic version of the Diabetes Quality of Life questionnaire. East Mediterr Health J. 2021;27(4):414-426. https://doi.org/10.26719/emhj.20.112

Received: 29/01/20; accepted: 22/04/20

Copyright (C) World Health Organization (WHO) 2021. Open Access. Some rights reserved. This work is available under the CC BY-NC-SA 3.0 IGO license (https://creativecommons.org/licenses/by-nc-sa/3.0/igo)

\section{Introduction}

Diabetes mellitus (DM) is a widespread disorder that effects patients from different age groups and sexes, and is a complex disease that involves both genetic and environmental factors. The most common forms of DM are type 1 and type 2 . Type 2 is characterized by insulin resistance and deficiency of insulin secretion. The $3 \mathrm{P}$ symptoms are hallmarks for DM: polydipsia, polyuria and polyphagia. Other symptoms may include losing weight, fatigue, and resistant sores (1). DM may cause several complications if not controlled properly, including cardiac disease, stroke, retinopathy that may progress to blindness, kidney failure, and limb amputations resulting from progression of diabetic foot problems.

Quality of life (QoL) is a wide concept with many domains that measures satisfaction with life. QoL includes both health-related and non-health-related aspects. Non-health-related domains include economic, political, and social factors. Health-related QoL (HRQoL) evaluates how a person perceives the effect of a disease and its treatment on the quality of their life (2). rather than on the presence or absence of an illness when measuring health status. The World Health Organization (WHO) defines HRQoL as an individual's physical, mental and social welfare and not only the absence of illness (3).
Diabetes has a huge effect on the lives of patients, because of constant constraints including dieting, exercising and regular monitoring of blood sugar levels, in addition to complications that affect HRQoL. In patients who have had DM for 15 years, 2\% may suffer from blindness, 10\% partial blindness, $30-45 \%$ some degree of retinopathy, $10-20 \%$ nephropathy, and $20-35 \%$ neuropathy (4). These complications decrease HRQoL and increase the cost of DM management. The gradual worsening of these complications further aggravates the anxiety and depression that people with diabetes may have (5), with an estimated $20.3 \%$ having depression (6), which correlates with low HRQoL (7). Other complications associated with DM can also decrease HRQoL, including sexual dysfunction (8). Depression can also increase progression of diabetes due to low medication compliance (9).

According to the International Diabetes Federation, $12.8 \%$ of adults aged $20-79$ years have diabetes, with 55 million people in the Middle East North Africa (MENA) region. This region has the second highest prevalence of diabetes after North America and the Caribbean (10). In the MENA region diabetes and related complications caused death to 418,900 deaths $-16.2 \%$ of all deaths in adults aged 20-79 years in 2019. The economic burden of the disease was estimated to be US\$2.9 billion in 2019 (10). The IDF 
estimates that $9.9 \%$ of Jordanians have diabetes (10). In 2015, disability-adjusted life years because of diabetes were 1052 among Jordanian men and 965 among women (11). According to the Global Health Data Exchange, 14.24\% of total deaths in Jordan in 2017 were caused by DM (12).

Therefore, a tool to measure HRQoL is important for appropriate management of DM; however, there is no validated tool for the Jordanian population. One widely used tool is the Diabetic Quality of Life (DQoL) questionnaire (13), which has demonstrated strong validity and reliability (14). The questionnaire has been translated into different languages and used in several countries including the United States of America (15), Malaysia (16), China (17), Turkey (18) and Spain (19). The DQoL questionnaire has been used in 82 studies (20); however, it has yet to be used in published studies in Arabic countries. The aims of the present study were, therefore, to validate an Arabic version of the questionnaire, evaluate QoL of patients with type 2 diabetes, and examine the factors that may influence it among the Jordanian population.

\section{Methods}

\section{Study design}

The current study validated an Arabic version of the DQoL questionnaire to measure QoL in people with type 2 diabetes. Patients were approached from 1 January to 30 April 2019, at 3 government health clinics in Jordan ( 2 in the capital Amman and 1 in Madaba). These clinics are characterized by close follow-up of patients and continuity of care as the patients must see a physician to obtain their prescriptions on a monthly basis. Two clinics were chosen from Amman as almost $42 \%$ (21) of the Jordanian population reside there. Additionally, the clinics in the capital serve many patients from the surrounding areas that lack proper medical services. The clinic in Madaba received patients from both urban and rural areas and $\sim 30 \%$ of Madaba residents reside in rural areas (21).

\section{Materials and procedure}

The DQoL questionnaire (Appendix 1) has been used for several years in several countries and in different languages. The questionnaire is composed of 46 items divided into 3 factors: satisfaction ( 15 items), impact ( 20 items) and worries (11 items divided into social/vocational and diabetes-related). The satisfaction and impact questions included a 5-point Likert scale [very satisfied (1 point), quite satisfied, satisfied, little satisfied, and very dissatisfied (5 points)]. In the original English-language questionnaire, questions related to worries about diabetes are divided into 2 sections: worries about social/vocational issues and worries about the future effects of diabetes. Responses to these are dichotomous with Yes or No options. However, having dichotomous and 5-point Likert scales may cause serious issues when attempting to validate questionnaires; therefore, these statements were converted to 5-point Likert scale responses.

Construction of the Arabic version of the DQoL questionnaire started with translation and selection of the items to be included; redundancy in questions were evaluated and duplicated items were omitted to shorten the questionnaire and improve factor loadings and discriminant validity. Prior to circulating the questionnaire, 20 other participants were given cognitive interviews to ensure that all questions were clear to the respondents. The data from these 20 participants were not included in the final data analysis.

Ethical approval was obtained from Al-Zaytoonah University and the 3 selected clinics. In addition to the DQoL questionnaire, a demographic data sheet was developed to obtain background information from participants including: sex, age, educational level, marital status, income level, and duration of illness. This data sheet, along with a consent form, a questionnaire that included other health-related questions and the final Arabic version of the DQoL questionnaire (Appendix 2) were circulated to 800 literate outpatients who had type 2 diabetes, and 725 of these agreed to participate. Relevant clinical indicators such as haemoglobin $(\mathrm{Hb})$ Alc, and diabetic complications and other comorbidities were collected from patients' medical records. Diabetic complications included diabetic foot, neuropathy, nephropathy, retinopathy and cardiovascular diseases (CVDs; e.g., stable and unstable angina pectoris, and myocardial infarction). Medication information was also obtained from the records.

There are several perspectives on how to estimate the appropriate sample size for factor analysis; some focus on the number of total participants, and others argue that sample size should be calculated using the ratio of the number of participants to number of items in the questionnaire, with a commonly suggested ratio of 20:1 (22). Therefore, to obtain an appropriate sample size in accordance with the previously mentioned approaches, we required a sample size of 700 participants.

The survey was translated by 2 independent bilingual translators, who were native Arabic speakers and proficient in English. The 2 translations were compared, and changes were made accordingly. The questionnaire was recirculated to 50 patients in their next follow-up visit to evaluate test-rest reliability. The follow-up visit was $\sim 30$ days after the index visit.

\section{Statistical analysis}

In the final data analysis, items were evaluated based on response rates; items that had $>10 \%$ missing answers were excluded. Estimation of missing values was important to recognize and ignore unrelated items. Prior to factor analysis, data imputation with maximization expectation procedure was applied to items that had missing data that did not reach the cut-off point of $10 \%$. Exploratory factor analysis (EFA) was conducted using principal component analysis to evaluate the most suitable model for the study data. The KaiserMeyer-Olkin value and Bartlett's Test of Sphericity were conducted to evaluate the suitability of the data for EFA. Communalities were examined, and any item $<0.4$ was deleted. Parallel analysis was conducted, and 
scree plots were examined to determine the appropriate number of factors to be extracted. A pattern matrix was generated using direct oblimin rotation, which was chosen because the factors were significantly correlated. Any item that had a loading $<0.4$ in all factors or had a loading of $\geq 0.4$ in more than 1 factor were excluded. Discriminant validity was evaluated by examining the factor correlation matrix. Internal consistency for each subscale was evaluated by calculating Cronbach's $\alpha$.

Confirmatory factor analysis (CFA) was conducted on the same data in accordance with Bengt Muthén's method, to evaluate the model fit by examining different indicators, including: CMIN/DF (minimum discrepancy), which has an acceptable range of 2-5; comparative fit index (CFI), and Tucker-Lewis coefficient (TLI), $\geq 0.9$ is considered acceptable; and root mean square error of approximation (RMESA), $\leq 0.08$ is considered acceptable. The percentage of participants who had the highest or lowest possible score were calculated to evaluate the presence of ceiling and floor effects; these effects were considered present if $>15 \%$ of the participants scored the maximum or minimum possible (23).

Four stepwise multiple linear regressions were conducted to evaluate factors associated with the DQoL questionnaire total mean score and the mean scores of each factor. These models included administration of insulin, glucagon-like peptide-1 receptor agonist, metformin, sulfonylurea, nonsulfonylurea, sodiumglucose cotransporter-2 inhibitors, dipeptidyl peptidase 4 inhibitors, and thiazolidinediones. The model also included number of drugs, number of complications (neuropathy, nephropathy, retinopathy, CVD, diabetic foot, hypertension or dyslipidaemia), HbAic level, married status, low income, number of years having diabetes, age, sex, body mass index, and smoking status. Log transformation was performed to achieve linearity. Cook's distance was calculated to measure the impact of influential cases on the model, and values $>1$ was considered problematic. Normality of errors was assessed by examining standardized residual histograms and variance inflation factor (VIF) was calculated to evaluate multicollinearity. Finally, independence of errors was evaluated by the Durbin-Watson test.

Pearson correlation was applied to evaluate testretest reliability. All statistical analysis was conducted using SPSS version 20 and Amos version 22.

\section{Results}

Nine duplicate items were identified and removed from the DQoL questionnaire (Table 1).

The questionnaires from 725 (378 male) participants were included in the analysis. The response rate was 90.6\%. Eight items were excluded from the analysis due to $>10 \%$ missing data; these items are listed in Table 2 .

Imputation of data on the remaining items was conducted using the maximization expectation procedure. EFA was conducted on the remaining 29 items; the characteristics of the sample are displayed in Table 3. The only significant difference found between the sexes was in smoking status, which was significantly higher in men.

Kaiser-Meyer-Olkin test result was 0.91 and Bartlett's Test of Sphericity was $\chi^{2}(406)=21975.94, P<0.01$. These results showed that the study data were suitable for factor analysis. Scree plots and parallel analysis indicated that a 3 -factor model was suitable for the study data.

The 3 factors were satisfaction, impact and worries. All the items included in the model loaded on their original factors as intended in the original English questionnaire. The communalities ranged between 0.45 and 0.95 and the loadings from 0.65 to 0.98 (Table 4). Cronbach's a indicated good internal consistency in all 3 factors.

The ceiling and floor effects were evaluated by calculating the percentage of participants that had the highest or lowest possible score, and none of factors reached the $15 \%$ cutoff point. CFA indicated a good fit for the suggested model: $\mathrm{CMIN} / \mathrm{DF}=4.88, \mathrm{CFI}=0.94, \mathrm{TLI}=$ 0.93 and RMSEA $=0.07$.

\section{Table 1 Items removed from Diabetes Quality of Life Questionnaire due to duplications}

\section{Item retained \\ Item removed}

S5. How satisfied are you with the flexibility you have in your diet?

S6. How satisfied are you with the burden your diabetes is placing on your family?

S8. How satisfied are you with your sleep?

S9. How satisfied are you with your social relationships and friendships?

S10. How satisfied are you with your sex life?

S13. How satisfied are you with the time you spend exercising?

S11. How satisfied are you with your work, school, and household activities?

S 14. How satisfied are you with your leisure time?
I9. How often do you feel restricted by your diet?

I5. How often does your diabetes interfere with your family life?

I6. How often do you have a bad night's sleep?

I7. How often do you find your diabetes limiting your social relationships and friendships?

I10. How often does your diabetes interfere with your sex life?

I12. How often does your diabetes interfere with your exercising?

I13. How often do you miss work, school, or household duties because of your diabetes?

W6. How often do you worry about whether you will miss work?

I15. How often do you find that your diabetes interrupts your leisure-time activities?

$I=$ impact $;=$ satisfaction; $W=$ worries. 


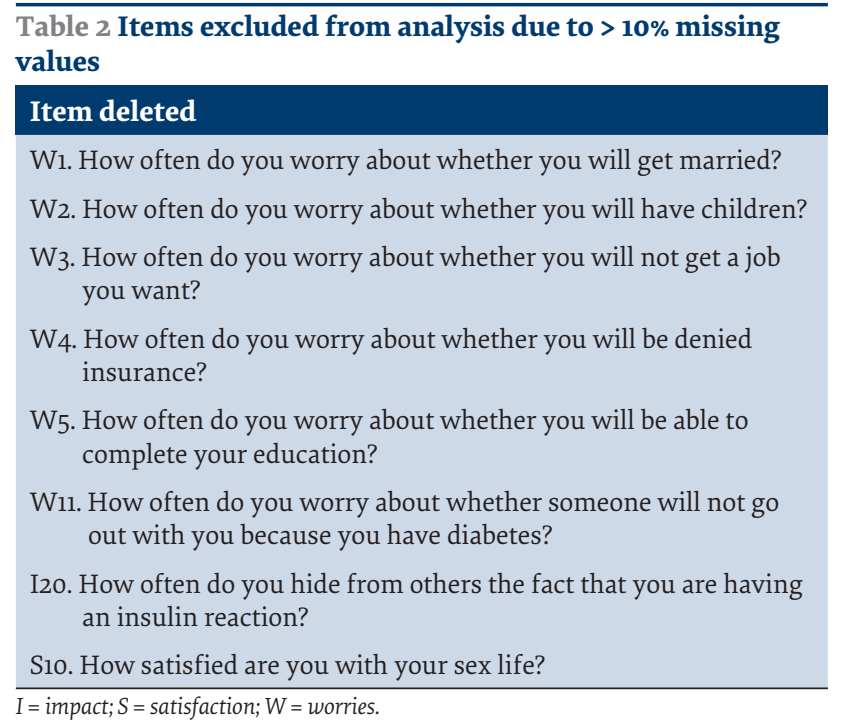

The stepwise linear multiple regression (Table 5) indicated that the mean of the total score of DQoL questionnaire was associated with $\mathrm{HbAlc}$, insulin treatment, number of complications, low-income group, diabetic foot, CVD and nephropathy. The model explained $52.4 \%$ of the variance, the mean score for the Satisfaction factor was associated with $\mathrm{HbAlc}$, insulin, diabetic foot, number of complications, being currently married, and CVD. The mean score for the Impact factor was associated with low income, HbArc, insulin treatment, nephropathy, number of complications, diabetic foot, and CVD. The mean score for the Worries factor was associated with number of complications, HbAlc, and low income.

Test-retest reliability was tested by using Pearson's correlations and all the items had a correlation $>0.8$, which indicated good test-retest reliability.

\section{Discussion}

We formulated and validated a summarized Arabic form of the DQoL questionnaire. The items in this study all loaded in their original designated scales in the original English questionnaire (13). However, our model consisted of 29 items loaded in 3 scales only, worry, impact and satisfaction, unlike the original model that included 46 items divided into 4 scales (13). This was mainly due to the exclusion of most of the items that were included in the vocational/social worry scale, mainly because of a high level of missing data (exceeding the 10\% threshold limit). These items were irrelevant to many of our respondents; for example, "How often do you worry about whether you will get married?" as many of recruits were already married. This applied to the rest of the deleted items that asked about concerns regarding completing their education, having children, getting a job and being covered by insurance. Additionally, item W6 was a duplicate of item S11; therefore, it was omitted from the questionnaire. The only item that remained from the original vocational/social worry scale was $\mathrm{W} 7$, which was loaded in the new worry scale. A previous study had also reported a large amount of missing data in these items as they did not apply to many of the respondents (16). The new formulated Worry scale comprised 4 items that were converted from dichotomous questions to 5-Likert scale questions to be more suitable for EFA. Other items from the Impact scale were also omitted to avoid redundancy, which shortened the 46-item lengthy survey to 29 items and improved its discriminant validity and factor loadings.

The results of the Arabic version were also compared with the Malaysian version of the DQoL questionnaire (16). The result of the present study resembled the 3 -factor model of the Malaysian version, which consists only of 18 items, as more items were dropped that were identified as duplications, including (I14) "How often do you find yourself explaining what it means to have diabetes?", and (I16) "How often do you tell others about your diabetes?". However, we felt that these 2 questions were not identical as explaining the impact of diabetes is different from merely stating that you have diabetes. Other items had low communalities and thus were not included in the Malaysian version.

Our study indicated that insulin has a negative effect on QoL. The literature reports contradictory finding when evaluating the effect of insulin therapy on QoL of people with diabetes (24). Insulin therapy can improve QoL (25), mainly due to better glycaemic control (26). In contrast, other studies have reported a negative effect of insulin therapy on QoL due to hypoglycaemic episodes (27), as well as the pain and inconvenience associated with insulin administration (28). Furthermore, insulin is usually prescribed in more severe cases (29) that are likely to have more complications. These conflicting findings may be due to variations in sampling and methodology (24), in addition to insulin type (25) and injection device (30). We also confirmed the previously reported association between HbAic and QoL (31). Better QoL is likely to lead to better self-care behaviour, which results in lower HbAic (9).

Currently married individuals had lower satisfaction when compared to unmarried patients. Several studies have reported a correlation between marital quality and adherence to diabetes care (32), and that marital stress is associated with an increase in serum glucose level due to the effect of stress hormones (32). The results of our study did not contain the omitted questions about sexual activity; if these questions were included this correlation may have been more significant.

As reported previously (33), low income was associated with low QoL. This may be attributed to the lack of knowledge of available options for managing DM (33), in addition to other lifestyle variables including nutritional intake.

Finally, as expected and as reported previously, the presence of different complications including diabetic foot CVD and nephropathy in addition to number of complications were all associated with lower QoL in our sample. 


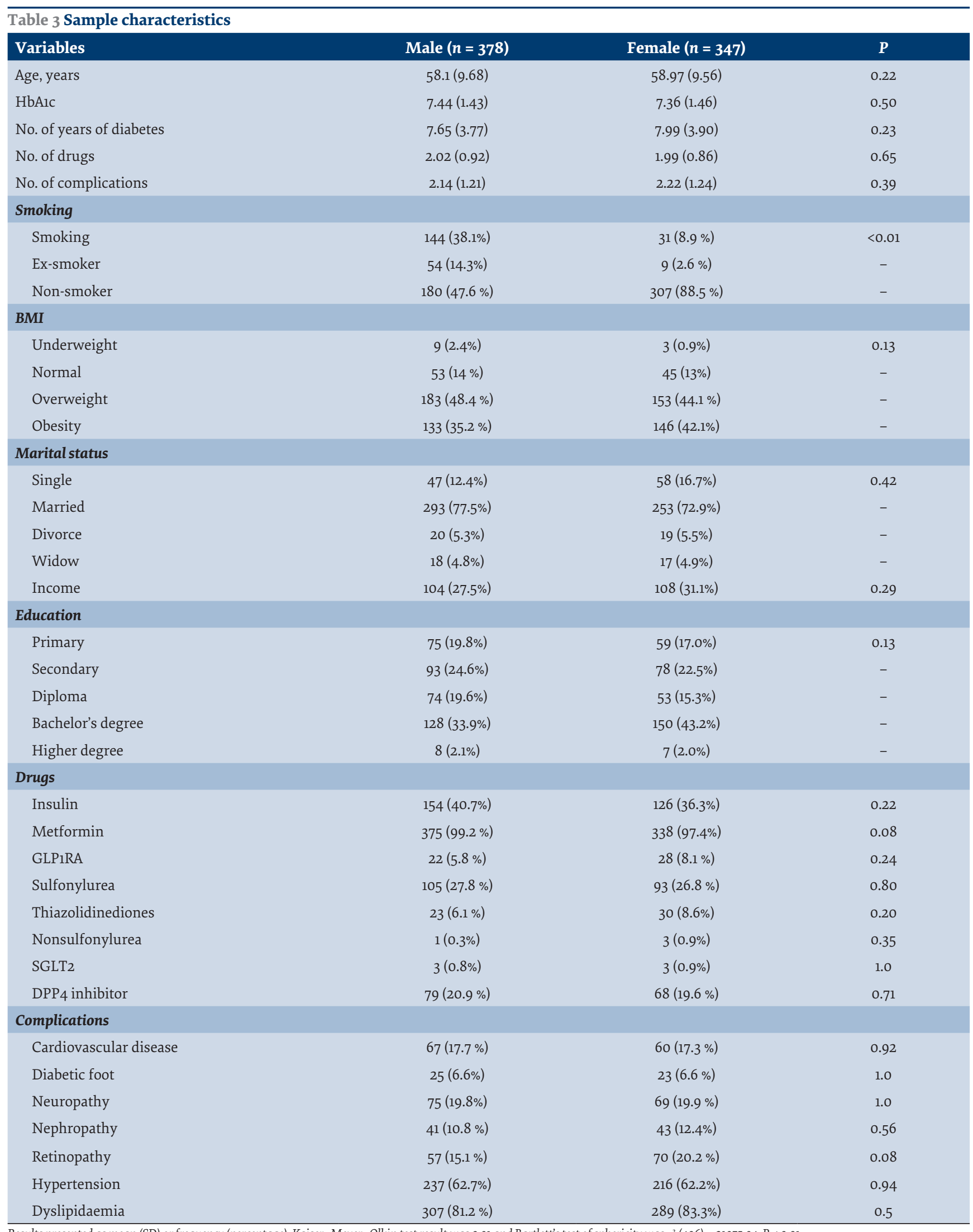

Results presented as mean (SD) or frequency (percentage). Kaiser-Meyer-Olkin test result was 0.91 and Bartlett's test of sphericity was $\chi^{2}(406)=21975.94, P<0.01$.

$\mathrm{BMI}=$ body mass index; DPP4 inhibitor = dipeptidyl peptidase-4 inhibitor; GLP1RA = glucagon-like peptide 1 receptor agonist; HbAlc = haemoglobin Alc; SGLT2 = sodium-glucose cotransporter 2 .

We conducted cognitive interviews to ensure that the questions were clear for our sample of patients. Additionally, the high internal consistency confirmed the clarity of the questionnaire. The Arabic version of the DQoL questionnaire can therefore be used to measure HRQoL in patients with diabetes. Evaluating QoL is important when treating people with diabetes, as patients with low HRQoL may not comply with 


\begin{tabular}{lcccccc}
\hline Table 4 Descriptive statistics and reliability of the Arabic version of Diabetes Quality of Life Questionnaire & \\
\hline $\begin{array}{l}\text { Domain } \\
\text { (item number) }\end{array}$ & Factor loading & $\begin{array}{c}\text { Communalities } \\
\text { (min-max) }\end{array}$ & $\begin{array}{c}\text { Cronbach's } \\
\alpha\end{array}$ & $\begin{array}{c}\text { Corrected item-total } \\
\text { correlation }\end{array}$ & Mean \\
Satisfaction items (S1-S9, S11-S15) & $0.65-0.98$ & $0.45-0.95$ & 0.97 & $0.63-0.97$ & 2.81 \\
Impact items (I1-I4, I8, I11, I14-I19) & $0.71-0.83$ & $0.52-0.71$ & 0.94 & $0.67-0.7$ & 2.06 & 2.39 \\
Worries items (W7-W10) & $0.79-0.91$ & $0.69-0.79$ & 0.88 & $0.73-0.75$ & \\
\hline
\end{tabular}

important medical instructions that influence control of their condition (9). Therefore, using the Arabic version of DQoL could help in the management of diabetes, and future work may include measuring the benefit of detection and management of DQoL when managing patients with diabetes in Jordan and neighbouring Arab countries. Furthermore, the Arabic version of the DQoL questionnaire can be used to compare the QoL in patients with diabetes in Arabic-speaking countries, which has not been possible until now. It will also be possible to make comparisons between HRQoL among patients with diabetes, relying on data collected using the Englishlanguage version of the questionnaire.

Our data showed some similarities and some differences with other work focusing on diabetes conducted in Arab countries. For example, using the Audit of Diabetes Dependent Quality of Life (ADDQOL19), Al-Shehri found that Saudi women with diabetes had significantly poorer QoL than men had (34). This replicates other research conducted in Gaza (35) using the WHO Quality of Life-BREF (WHOQOL-BREF), which found that women with diabetes were more negatively affected than men. These findings contrast with ours, but as Al-Shehri noted, such differences may be in part due to wider gender inequalities in some communities, which were perhaps less evident in our Jordanian sample. Our results do replicate those of other work in relation to complications. We found poorer QoL for those with complications, supporting studies in Saudi Arabia using the Short Form-36 questionnaire (SF-36).
One limitation of our study was that illiterate patients were not included, who may have struggled more with medication instructions related to the management of their condition. Another limitation was that dropping the 17 questions could have affected the content validity of the questionnaire, particularly the impact of diabetes on sex life, and may not have captured the complete impact of diabetes in all groups. However, summarizing the questionnaire and limiting duplication will encourage patients to participate and complete the questionnaire accurately. Furthermore, this summarized version is more applicable to all ages and different marital status, which makes it easier to conduct in a general setting without needing different versions for specific groups. Moreover, in a conservative society as in Jordan and other Arabic countries, many would be reluctant to talk openly about their sexual activities. In fact, high nonresponse rates have been reported in privacy-related items from the DQoL questionnaire, in addition to many respondents complaining about the length of the questionnaire.

\section{Conclusion}

This validated Arabic version of the DQoL questionnaire could be used to evaluate HRQoL in Arab-speaking patients by examining the overall score and the scores of the different subscales. This could aid with diagnosis and management of DM in Jordan and neighbouring countries.

Funding: None.

Competing interests: None declared.

\begin{tabular}{|c|c|c|c|c|c|c|c|c|c|c|c|c|}
\hline \multirow[t]{2}{*}{ Variables } & \multicolumn{3}{|c|}{ Mean total score } & \multicolumn{3}{|c|}{ Satisfaction } & \multicolumn{3}{|c|}{ Impact } & \multicolumn{3}{|c|}{ Worry } \\
\hline & $\beta$ & $P$ value & $95 \% \mathrm{CI}$ & $\beta$ & $P$ value & $95 \% \mathrm{CI}$ & $\beta$ & $P$ value & $95 \% \mathrm{CI}$ & $\beta$ & $P$ value & $95 \% \mathrm{CI}$ \\
\hline HbAlc & 0.15 & $<0.01$ & $0.13-0.17$ & 0.17 & $<0.01$ & $0.13-0.20$ & 0.15 & $<0.01$ & $0.12-0.18$ & 0.11 & $<0.01$ & $0.06-0.15$ \\
\hline Insulin & 0.24 & $<0.01$ & $0.18-0.31$ & 0.23 & $<0.01$ & $0.13-0.33$ & 0.31 & $<0.01$ & $0.21-0.4$ & & $\mathrm{~N} / \mathrm{S}$ & \\
\hline Low income & 0.19 & $<0.01$ & $0.12-0.26$ & & $\mathrm{~N} / \mathrm{S}$ & & 0.59 & $<0.01$ & $0.48-0.69$ & 0.15 & 0.022 & $0.02-0.28$ \\
\hline Currently married & & $\mathrm{N} / \mathrm{S}$ & & 0.16 & $<0.01$ & $0.05-0.27$ & & $\mathrm{~N} / \mathrm{S}$ & & & $\mathrm{N} / \mathrm{S}$ & \\
\hline Diabetic foot & 0.3 & $<0.01$ & $0.16-0.42$ & 0.33 & $<0.01$ & $0.11-0.54$ & 0.28 & $<0.01$ & $0.08-0.49$ & & $\mathrm{~N} / \mathrm{S}$ & \\
\hline CVDs & 0.19 & $<0.01$ & $0.01-0.28$ & 0.20 & $<0.01$ & $0.06-0.34$ & 0.21 & $<0.01$ & $0.07-0.34$ & & $\mathrm{~N} / \mathrm{S}$ & \\
\hline Nephropathy & 0.18 & $<0.01$ & $0.08-0.29$ & & $\mathrm{~N} / \mathrm{S}$ & & 0.33 & $<0.01$ & $0.17-0.49$ & & $\mathrm{~N} / \mathrm{S}$ & \\
\hline Total complications & 0.11 & $<0.01$ & $0.08-0.15$ & 0.12 & $<0.01$ & $0.10-0.18$ & 0.09 & $<0.01$ & $0.03-0.14$ & 0.16 & $<0.01$ & $0.10-0.21$ \\
\hline
\end{tabular}




\section{Élaboration et validation de la version arabe du questionnaire sur la qualité de vie des patients diabétiques}

\section{Résumé}

Contexte: Le questionnaire sur la qualité de vie des patients diabétiques est fréquemment utilisé auprès de ces derniers.

Objectifs: Élaborer et valider une version arabe révisée du questionnaire sur la qualité de vie des patients diabétiques pour les patients jordaniens atteints de diabète de type 2 .

Méthodes: Nous avons recruté des patients atteints de diabète de type 2 dans trois centres de santé publique en Jordanie. Le questionnaire original a été traduit en arabe. Il a ensuite fait l'objet d'une rétro-traduction par un traducteur différent, et les deux versions ont été comparées. Avant de diffuser la version finale du questionnaire, un test de validité cognitive a été appliqué pour s'assurer que toutes les questions étaient claires. La version arabe finale du questionnaire sur la qualité de vie des patients diabétiques, ainsi qu'un questionnaire comportant des questions démographiques et d'autres questions liées à la santé, ont été distribués aux participants. Les données issues du questionnaire ont été analysées à l'aide d'une analyse factorielle exploratoire et d'une analyse factorielle confirmatoire après exclusion des questions dupliquées et des questions comportant plus de $10 \%$ de données manquantes. Le coefficient alpha de Cronbach a également été réalisé pour confirmer la cohérence interne.

Résultats: L'analyse a permis de valider une version arabe du questionnaire comprenant 29 items répartis selon trois facteurs : inquiétudes, impact et satisfaction. Différentes variables ont été associées aux scores du questionnaire sur la qualité de vie des patients diabétiques, notamment l'administration d'insuline, le statut de revenu faible, le statut marital et la présence de complications diabétiques.

Conclusions: Nous avons validé un outil en arabe qui peut être utilisé pour évaluer la qualité de vie chez les patients arabophones atteints de diabète de type 2 .

$$
\begin{aligned}
& \text { إعداد النسخة العربية لاستبيان جودة الحياة لمرضى داء السُّكَّيّ و التحقق من صحتها } \\
& \text { وليد القريم، بثينة المعيا، جوناثان لينج }
\end{aligned}
$$

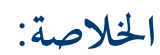

$$
\begin{aligned}
& \text { الخلفية: كان استبيان جودة الحياة لمرضى داء السُكَّريّ يُستخدم كثيراً بين الأشخاص المصابين بداء السُكَّريّ. }
\end{aligned}
$$

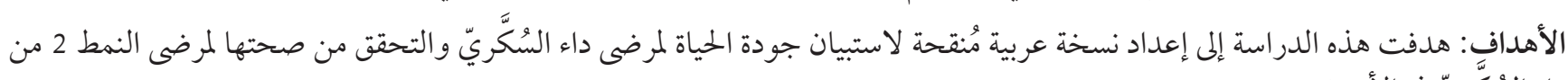

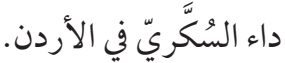

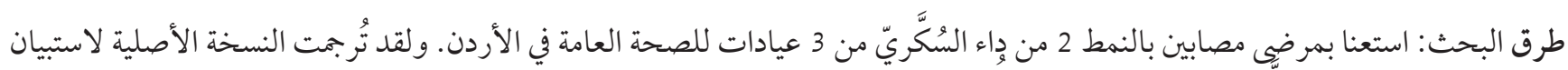

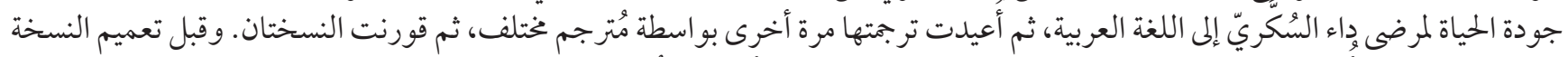

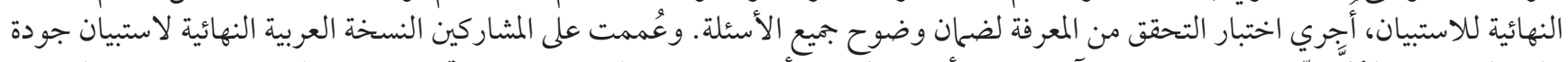

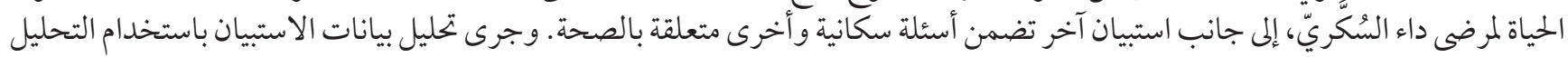

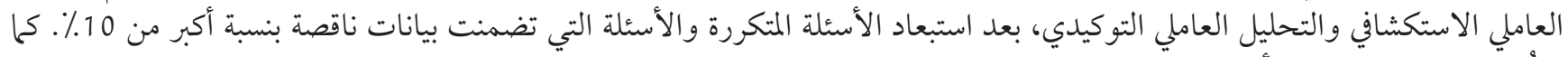

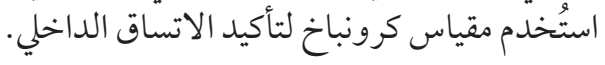

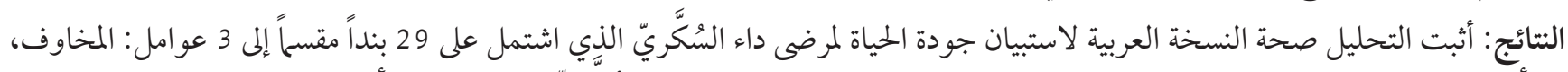

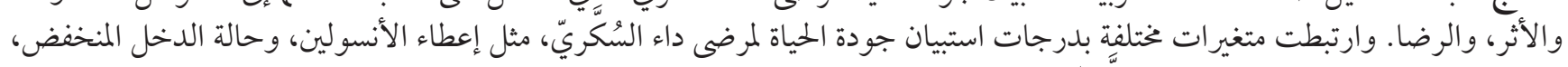

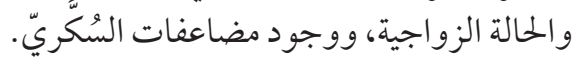

$$
\begin{aligned}
& \text { الاستنتاجات: تحققنا من صحة أداة عربية يمكن استخدامها لتقييم استبيان جودة الحياة بين مرضى النمط } 2 \text { من داء السُكَّريّ الناطقين باللغة العربية. }
\end{aligned}
$$

\section{References}

1. $\quad$ Bastaki S. Review. Diabetes mellitus and its treatment. Int J Diabetes Metab. 2005;13:111-34.

2. Tarumi K, Imanaka Y, Isshiki Y, Morimoto K. Quality of life domains in the healthy public: A trial investigation using attendants for an annual health checkup. Environ Health Prev Med. 1999 Apr;4(1):39-48. http://dx.doi.org/10.1007/BF02931249 PMID:21432170

3. Trikkalinou A, Papazafiropoulou AK, Melidonis A. Type 2 diabetes and quality of life. World J Diabetes. 2017 Apr 15;8(4):120-9. http://dx.doi.org/10.4239/wjd.v8.i4.120 PMID:28465788 
4. Faria HTG, Veras VS, Xavier AT da F, Teixeira CR de S, Zanetti ML, dos Santos MA. Quality of life in patients with diabetes mellitus before and after their participation in an educational program. Rev da Esc Enferm. 2013;47(2):344-9 (in Portuguese). https:// doi.org/10.1590/Soo80-62342013000200011

5. Grandy S, Chapman RH, Fox KM. Quality of life and depression of people living with type 2 diabetes mellitus and those at low and high risk for type 2 diabetes: findings from the Study to Help Improve Early evaluation and management of risk factors Leading to Diabetes (SHIELD). Int J Clin Pract. 2008 Apr;62(4):562-8. http://dx.doi.org/10.1111/j.1742-1241.2008.01703.x PMID:18266708

6. Salinero-Fort MA, Gomez-Campelo P, Andres-Rebollo FJS, Cardenas-Valladolid J, Abanades-Herranz JC, De Santa Pau EC, et al. Prevalence of depression in patients with type 2 diabetes mellitus in Spain (the DIADEMA Study): results from the MADIABETES cohort. BMJ Open. 2018 Sep 24;8(9):e020768. http://dx.doi.org/10.1136/bmjopen-2017-020768 PMID:30249627

7. Schram M, Baan C, Pouwer F. Depression and quality of life in patients with diabetes: a systematic review from the European Depression in Diabetes (EDID) Research Consortium. Curr Diabetes Rev. 2009 May;5(2):112-9. http://dx.doi. org/10.2174/157339909788166828 PMID:19442096

8. De Berardis G, Franciosi M, Belfiglio M, Di Nardo B, Greenfield S, Kaplan SH, et al. Erectile dysfunction and quality of life in type 2 diabetic patients: a serious problem too often overlooked. Diabetes Care. 2002 Feb;25(2):284-91. http://dx.doi.org/10.2337/ diacare.25.2.284 PMID:11815497

9. Gonzalez JS, Peyrot M, McCarl LA, Collins EM, Serpa L, Mimiaga MJ, et al. Depression and diabetes treatment nonadherence: a meta-analysis. Diabetes Care. 2008 Dec;31(12):2398-403. http://dx.doi.org/10.2337/dc08-1341 PMID:19033420

10. International Diabetes Federation. IDF diabetes atlas, 9th edition [website] (https://diabetesatlas.org/upload/resources/material/20200302_133351_IDFATLAS9e-final-web.pdf\#page=74\&zoom=100,0,0, accessed 21 August 2020).

11. Moradi-Lakeh M, El Bcheraoui C, Khalil I, Charara R, Afshin A, Wang H, et al. Diabetes mellitus and chronic kidney disease in the Eastern Mediterranean Region: findings from the Global Burden of Disease 2015 study. Int J Public Health. 2018 May;63(Suppl 1):177-86. http://dx.doi.org/10.1007/s00038-017-1014-1 PMID:28776240

12. Global Health Data Exchange. GBD Compare | IHME Viz Hub [website] (https://vizhub.healthdata.org/gbd-compare/, accessed 21 August 2020).

13. The DCCT Research Group. Reliability and validity of a diabetes quality-of-life measure for the Diabetes Control and Complications Trial (DCCT). Diabetes Care 1988 Oct;11(9):725-32. https://doi.org/10.2337/diacare.11.9.725

14. The Diabetes Control and Complications Trial Research Group. Influence of intensive diabetes treatment on quality-of-life outcomes in the Diabetes Control and Complications Trial. Diabetes Care. 1996 Mar;19(3):195-203. https://doi.org/10.2337/diacare.19.3.195

15. Jacobson AM, De Groot M, Samson JA. The evaluation of two measures of quality of life in patients with type I and type II diabetes. Diabetes Care. 1994 Apr;17(4):267-74. http://dx.doi.org/10.2337/diacare.17.4.267 PMID:8026281

16. Bujang MA, Adnan TH, Mohd Hatta NKB, Ismail M, Lim CJ. A revised version of Diabetes Quality of Life Instrument maintaining domains for satisfaction, impact, and worry. J Diabetes Res. 2018 Jul 22;2018:5804687. http://dx.doi.org/10.1155/2018/5804687 PMID:30327784

17. Cheng AY, Tsui EY, Hanley AJG, Zinman B. Developing a quality of life measure for Chinese patients with diabetes. Diabetes Res Clin Pract. 1999 Dec;46(3):259-67. https://doi.org/10.1016/S0168-8227(99)00091-1

18. Yildirim A, Akinci F, Gozu H, Sargin H, Orbay E, Sargin M. Translation, cultural adaptation, cross-validation of the Turkish Diabetes Quality-of-Life (DQOL) measure Qual Life Res. 2007 Jun;16(5):873-9 http://dx.doi.org/10.1007/s11136-007-9172-x PMID:17286193

19. Reviriego J, Millan MD, Millan M. Evaluation of the diabetes quality-of-life questionnaire in a Spanish population. An experience of translation and reliability. Pharmacoeconomics. 1996 Dec;10(6):614-22. http://dx.doi.org/10.2165/00019053-19961006o00007 PMID:10164061

20. Pereira EV, Tonin FS, Carneiro J, Pontarolo R, Wiens A. Evaluation of the application of the Diabetes Quality of Life Questionnaire in patients with diabetes mellitus. Arch Endocrinol Metab. 2020 Jan 1;64(1):59-65. https://doi.org/10.20945/23593997000000196

21. Jordanian Department of Statistics. 2019 fact sheets [website] (http://dosweb.dos.gov.jo/DataBank/Population_Estimares/PopulationEstimates.pdf, accessed 21 August 2020).

22. Costello AB, Osborne JW. Best practices in exploratory factor analysis: four recommendations for getting the most from your analysis. Pract Assess Res Eval. 2005;10, Article 7. https://doi.org/10.7275/jyj1-4868

23. McHorney CA, Tarlov AR. Individual-patient monitoring in clinical practice: are available health status surveys adequate? Qual Life Res. 1995 Aug;4(4):293-307. http://dx.doi.org/10.1007/BF01593882 PMID:7550178

24. Davis TM, Clifford RM, Davis WA, Fremantle Diabetes Study. Effect of insulin therapy on quality of life in type 2 diabetes mellitus: the Fremantle Diabetes Study. Diabetes Res Clin Pract. 2001 Apr;52(1):63-71. http://dx.doi.org/10.1016/s0168-8227(00)00245-x PMID:11182217

25. Bebakar WMW, Lim-Abrahan MA, Jain AB, Seah D, Soewondo P. Safety and effectiveness of insulin aspart in type 2 diabetic patients: results from the ASEAN cohort of the Alchieve study. Diabetes Res Clin Pract. 2013 Apr;100(Suppl. 1):S17-23. https://doi. org/10.1016/S0168-8227(13)70005-6 
26. Pouwer F, Hermanns N. Insulin therapy and quality of life. A review. Diabetes Metab Res Rev. 2009 Sep;25 Suppl 1:S4-10. http:// dx.doi.org/10.1002/dmrr.981 PMID:19662621

27. Vijan S, Hayward RA, Ronis DL, Hofer T. Brief report: The burden of diabetes therapy: Implications for the design of effective patient-centered treatment regimens. J Gen Intern Med. 2005 May;20(5):479-82. http://dx.doi.org/10.1111/j.1525-1497.2005.0117.x PMID:15963177

28. Ishii H, Terauchi $Y$, Jinnouchi $H$, Taketsuna M, Takeuchi M, Imaoka T. Effects of insulin changes on quality of life and glycemic control in Japanese patients with type 2 diabetes mellitus: The insulin-changing study intending to gain patients' insights into insulin treatment with patient-reported health outcomes in actual clinical treatments (INSIGHTs) study. J Diabetes Investig. 2013 Nov 27;4(6):560-70. http://dx.doi.org/10.1111/jdi.12086 PMID:24843710

29. Fertig BJ, Simmons DA, Martin DB. Therapy for diabetes. In: Diabetes in America. 2nd edition. Washington, DC: National Diabetes Data Group; 1995:519-40.

30. De Luis DA, Aller R, Cuellar L, Terroba MC, Ovalle HF, Izaola O, et al. Effect on quality of life with a new insulin injection device in elderly patients with diabetes mellitus type 2. J Diabetes Complications. 2004 Jul-Aug;18(4):216-9. http://dx.doi.org/10.1016/ S1056-8727(03)00089-8 PMID:15207839

31. Lu Y, Wang N, Chen Y, Nie X, Li Q, Han B, et al. Health-related quality of life in type-2 diabetes patients: a cross-sectional study in East China. BMC Endocr Disord. 2017 Jul 6;17(1):38. http://dx.doi.org/10.1186/s12902-017-0187-1 PMID:28683734

32. Liu H, Waite L, Shen S. Diabetes risk and disease management in later life: a national longitudinal study of the role of marital quality. J Gerontol B Psychol Sci Soc Sci. 2016 Nov 1;71(6):1070-80. http://dx.doi.org/10.1093/geronb/gbw061 PMID:27216861

33. Camacho F, Anderson RT, Bell RA, Goff DC, Duren-Winfield V, Doss DD, et al. Investigating correlates of health related quality of life in a low-income sample of patients with diabetes. Qual Life Res. 2002 Dec;11(8):783-96. http://dx.doi. org/10.1023/a:1020858102483 PMID:12482162

34. Al-Shehri FS. Quality of life among Saudi diabetics. J Diabetes Mellit. 2014 Aug;4(3):225-31. http://dx.doi.org/10.4236/ jdm.2014.43032

35. Eljedi A, Mikolajczyk RT, Kraemer A, Laaser U. Health-related quality of life in diabetic patients and controls without diabetes in refugee camps in the Gaza strip: A cross-sectional study. BMC Public Health. 2006 Oct 30;6:268. http://dx.doi.org/10.1186/14712458-6-268 PMID:17074088 


\section{Appendix 1. Original Diabetes Quality of Life Questionnaire}

\section{Satisfaction}

1. How satisfied are you with the amount of time it takes to manage your diabetes?

2. How satisfied are you with the amount of time you spend getting checkups?

3. How satisfied are you with the time it takes to determine your sugar level?

4. How satisfied are you with your current treatment?

5. How satisfied are you with the flexibility you have in your diet?

6. How satisfied are you with the burden your diabetes is placing on your family?

7. How satisfied are you with your knowledge about your diabetes?

8. How satisfied are you with your sleep?

9. How satisfied are you with your social relationships and friendships?

10. How satisfied are you with your sex life?

11. How satisfied are you with your work, school, and household activities?

12. How satisfied are you with the appearance of your body?

13. How satisfied are you with the time you spend exercising?

14. How satisfied are you with your leisure time?

15. How satisfied are you with life in general?

\section{Impact}

1. How often do you feel pain associated with the treatment for your diabetes?

2. How often are you embarrassed by having to deal with your diabetes in public?

3. How often do you have low blood sugar?

4. How often do you feel physically ill?

5. How often does your diabetes interfere with your family life?

6. How often do you have a bad night's sleep?

7. How often do you find your diabetes limiting your social relationships and friendships?

8. How often do you feel good about yourself?

9. How often do you feel restricted by your diet?

10. How often does your diabetes interfere with your sex life?

11. How often does your diabetes keep you from driving a car or using a machine (e.g., a typewriter)?

12. How often does your diabetes interfere with your exercising?

13. How often do you miss work, school, or household duties because of your diabetes?

14. How often do you find yourself explaining what it means to have diabetes?

15. How often do you find that your diabetes interrupts your leisure-time activities?

16. How often do you tell others about your diabetes?

17. How often are you teased because you have diabetes?

18. How often do you feel that because of your diabetes you go to the bathroom more than others?

19. How often do you find that you eat something you shouldn't rather than tell someone that you have diabetes?

20. How often do you hide from others the fact that you are having an insulin reaction? 


\section{Worry: social/vocational}

1. How often do you worry about whether you will get married?

2. How often do you worry about whether you will have children?

3. How often do you worry about whether you will not get a job you want?

4. How often do you worry about whether you will be denied insurance?

5. How often do you worry about whether you will be able to complete your education

6. How often do you worry about whether you will miss work?

7. How often do you worry whether you will be able to take a vacation?

\section{Worry: diabetes-related}

8. How often do you worry about whether you will pass out?

9. How often do you worry that your body looks different because you have diabetes?

10. How often do you worry that you will get complications from your diabetes?

11. How often do you worry about whether someone will not go out with you because

you have diabetes? 


$$
\begin{aligned}
& \text { القسم الأول: المعلومات الشخصية } \\
& \text { 1- الجنس : ذكر } \square \\
& \text { 2- العمر: } \\
& \text { 3- المستوى التعليمي : }
\end{aligned}
$$

1 - ابتدائي

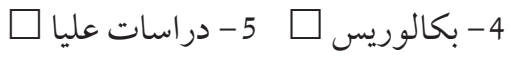

\begin{tabular}{|c|c|c|c|c|c|c|}
\hline 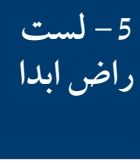 & 4اضي بعض لست & 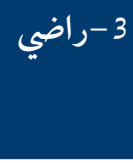 & الثضيء & 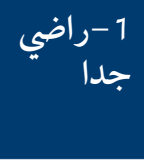 & العبارة & الرقم \\
\hline & & & & & ما مدى رضاك رضكري عن مقدار الوقت الذي تستغرقه لعلاج & -1 \\
\hline & & & & & ما مدى رضاك عن مقدار الوقت الذي تقضيه في إجراء & -2 \\
\hline & & & & & مستوى السكر رضاك عن الوقت الذي تستغرقه لفحص & -3 \\
\hline & & & & & ما مدى رضاك عن علاجك الحالي؟ & -4 \\
\hline & & & & & ما مدى رضاك عن مرونة نظامك الغذائي؟ & -5 \\
\hline & & & & & ما مدى رضا العبء الذي يفرضه مرضك على عائلتك؟ & -6 \\
\hline & & & & & ما مدى رضاك عن معرفتك بمرض السكري؟ & -7 \\
\hline & & & & & ما مدى رضاك عن نمط نومك؟ & -8 \\
\hline & & & & & ما مدى رضاك عن علاقاتك الاجتماعية؟ & -9 \\
\hline & & & & & ما مدى رضاك عن عملك ومدرستك وأنشطتك & -10 \\
\hline & & & & & ما مدى رضاك عن مظهر جسمك؟ & -11 \\
\hline
\end{tabular}

4 - الحالة الاجتحاعية : - n

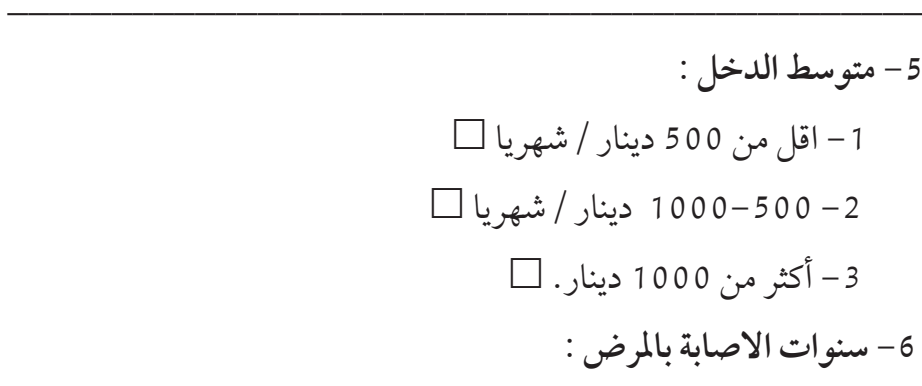

القسم الثاني : مستوى الرضا 


\begin{tabular}{|c|c|c|c|c|c|c|}
\hline 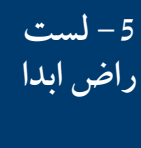 & الشى بـ بعض اضت & 3-راضي & الشيء & 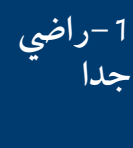 & العبارة & 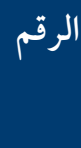 \\
\hline & & & & & الرياضية؟ رضاك عن كمية الوقت الذي تقضيه في التهارين & -12 \\
\hline & & & & & ما مدى رضاك (اك عن كيفية قضاء وقت فراغك & -13 \\
\hline & & & & & ما مدى رضاك عن الحياة بشكل عام؟ & -14 \\
\hline
\end{tabular}

القسم الثالث: التأثير

\begin{tabular}{|r|r|r|r|r|c|}
\hline & & & \\
\hline \\
\hline
\end{tabular}

$$
\text { القسم الر ابع: القلق ذو صلة بمرض السكري }
$$

\begin{tabular}{|c|c|c|c|c|c|c|}
\hline 5-طوال & 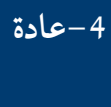 & 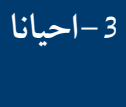 & 2-قدا & 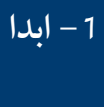 & 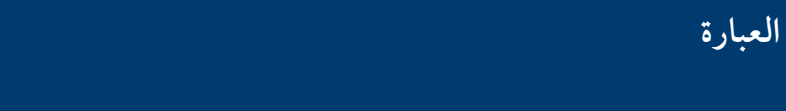 & 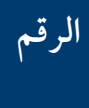 \\
\hline & & & & & هل تقلق فيما يتعلق بقدرتك على أخذ إجازة؟ & -1 \\
\hline & & & & & هل تقلق بشأن تغيّبك عن الوعي عادة؟ & -2 \\
\hline & & & & & هل تقلق بسبب اختلاف شكل جسدك بسبب مرض السكري؟ & -3 \\
\hline & & & & & هل تقلق بشأن تعرضك لمضاعفات مرض السكري في المستقبل؟ & -4 \\
\hline
\end{tabular}

